\title{
Emergency at the Zoo: An Orangutan Bite Resulting in Thumb Amputation and
}

\section{Forearm Laceration}

\author{
Shaza Aouthmany MD ,Noah Alcodray BA, Nasheed Fakhouri DO \\ Department of Emergency Medicine, University of Toledo College of Medicine and Life Sciences, Toledo, $\mathrm{OH}$
}

*Corresponding author: Shaza Aouthmany MD, Department of Emergency Medicine, University of Toledo College of Medicine and Life Sciences, Toledo, Email: shaza.aouthmany@utoledo.edu

\section{Abstract}

Zoos and aquariums receive over 180 million visitors per year. Although this amount of traffic is equivalent to over half the US population, traumatic injuries at modern zoo enclosures are rare. Despite adequate safety standards, proper training, and experience with animals, incidents may occur that require extensive medical management. We report the case of a 57-year-old woman who presented to the emergency department after being bitten by an orangutan resulting in right disarticulation of her right thumb and a laceration to her right forearm.

\section{Introduction}

Primates are an order within the class of Mammalia and include humans, gorillas, orangutans, chimpanzees, among many others. Simians are an infraorder within the Primate order but encompass the species stated above [1,2]. Such exotic animals are kept in zoos all over the world and require close human interaction in order to be fed and to be treated medically. These interactions pose a risk for serious injury. While there are countless studies on bites from dogs, cats, and other animals, there are no case reports on orangutan bites. We present a case of thumb amputation and forearm laceration from an orangutan bite to an animal caretaker.

\section{Case Summary}

A 57-year-old, right-handed, female patient with no significant past medical history arrived via EMS from a local zoo for right thumb amputation and forearm laceration after being bitten by an orangutan. The patient, an animal caretaker, was feeding the primate when it grabbed the patient's right upper extremity through its cage. Orangutan initially bit into right hand disarticulating patient thumb and then into into right medial forearm . EMS reported an arterial bleed and applied a tourniquet on the scene.

On presentation patient was alert and oriented $\mathrm{x} 4$, had blood pressure 149/71 $\mathrm{mmHg}$, pulse rate 95 beats/min, respirations 12 breaths/min, and pulse oximetry $100 \%$ on room air. Bleeding was well controlled with the tourniquet in place.. There was obvious amputation of the right thumb which was hanging by approximately $15 \mathrm{~cm}$ of avulsed extensor pollicis longus and flexor pollicis longus tendons. The right forearm had significant soft tissue damage from laceration on the medial aspect with musculature and tendon exposed. There was no evidence of compartment syndrome and the distal circulation was intact. The patient was able to move her right second through fifth digits. No sensory deficits were elicited. The remainder of the physical exam was unremarkable.

The patient was given a $0.5 \mathrm{~mL}$ Tdap injection IM, 3000 $\mathrm{mg}$ IV ampicillin-sulbactam was given along with $50 \mathrm{mcg}$ IV fentanyl and the tourniquet was removed. Radiograph of the right hand revealed complete amputation of the first digit at the metacarpophalangeal joint (Figure 1). Radiographs of the right forearm demonstrated minimally displaced distal ulnar styloid fracture and large soft tissue laceration with associated soft tissue hematoma (Figure 2). Orthopedic surgery and vascular surgery were consulted and patient was taken emergently to the operating room for wound exploration, replantation, and wound closure.

\section{Discussion}

Patients with bite injuries comprise about $1 \%$ of visits to the emergency department annually $[3,4]$. In 2009, animal-related injuries accounted for 1.3 million emergency department visits, 60,800 of which led to in-patient stays. Of 


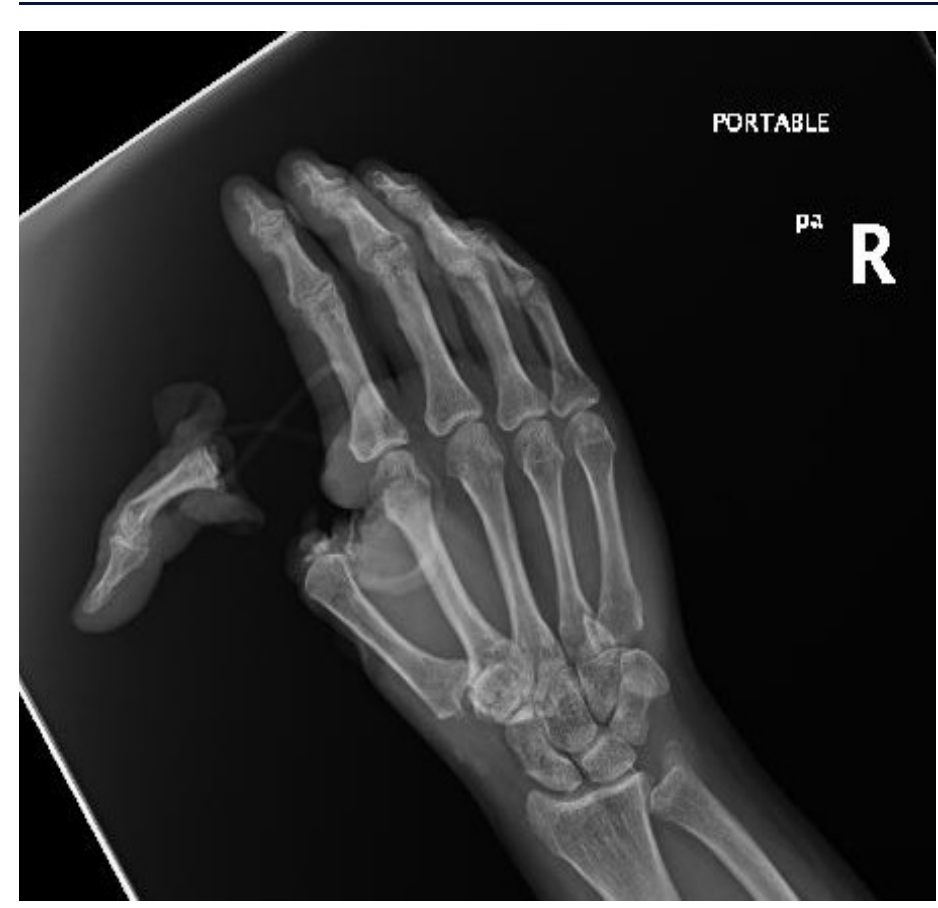

Figure 1: Primary bite injury to right hand. Right thumb amputation evident on film.

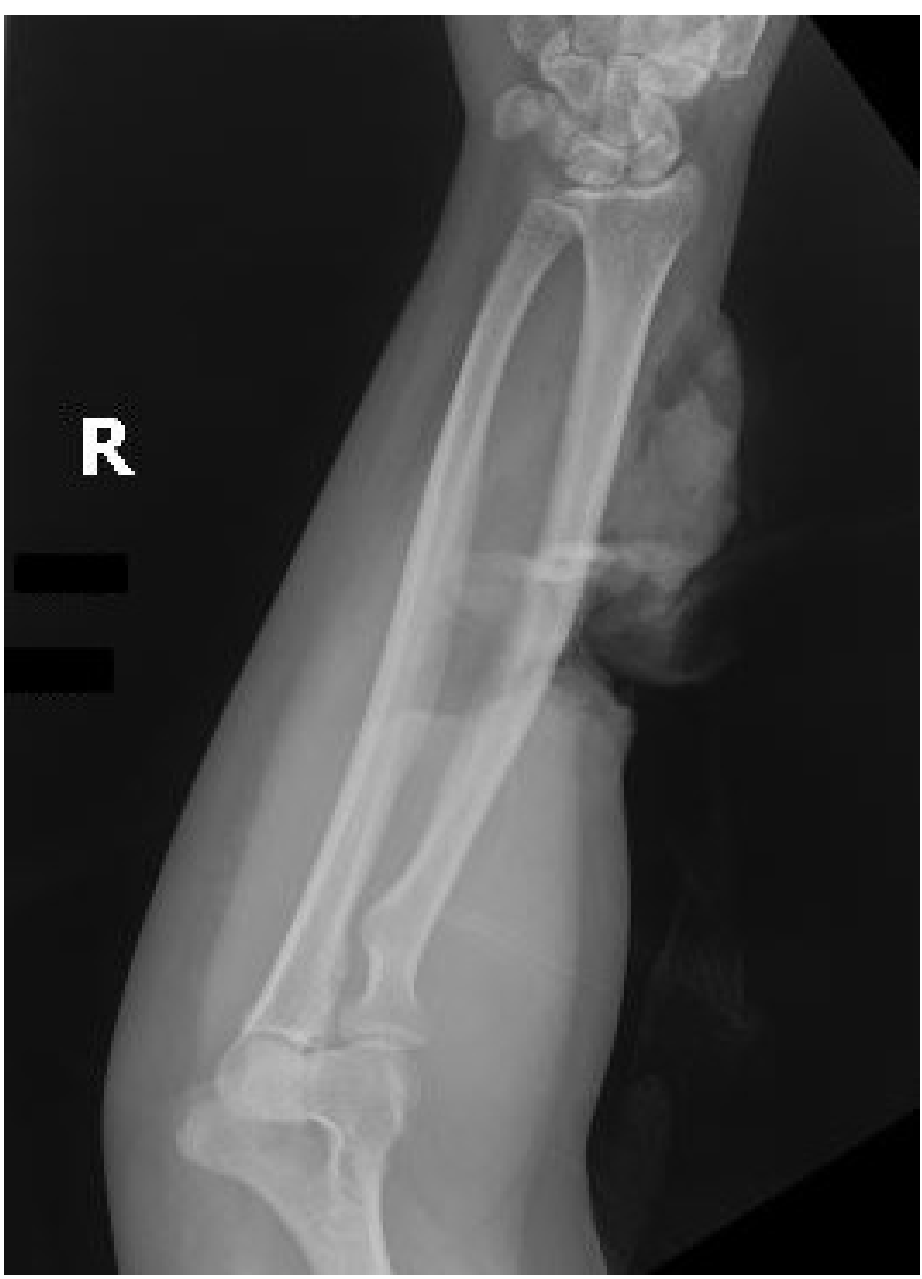

Figure 2: Secondary bite injury to right forearm. Laceration and ulnar styloid fracture evident on film. these in-patient stays, 9,700 were related to animals other than dogs [5]. These 'other animal' injuries may not be as well studied as dog bites, but information available allows for physicians to make clinically sound decisions. As far as we know, there are no published studies on orangutan bites specifically, and as such we review information regarding the complications, treatment of, and risk of infection from nonhuman primate bites.

Bite injuries from mammals have the potential for a wide range of damage to the recipient, from a simple abrasion to the more concerning laceration, avulsion, fracture, and amputation [4]. To put the potential for injury from an orangutan bite into perspective, consider that an African lion has a bite force of over $4000 \mathrm{~N}$, an orangutan almost $2000 \mathrm{~N}$, and a human about a third of an orangutan [6].

The most common complication of mammal bite injuries is infection, which in turn can progress to osteomyelitis, tenosynovitis, and cellulitis. 4 Current data suggests a similarity between the bacteria isolated from simian bites and that which is isolated from human bites which includes alpha-hemolytic streptococci, S. aureus, Neisseria species, Eikenella corrodens, anaerobes, and Enterobacteriaceae $[7,8]$. Left untreated, human bites have an infection rate of $48 \%$, so it is imperative to adequately treat orangutan bites [4].

Treatment principles outlined for animal bites include some combination of irrigation, prophylactic antibiotics, targeted antibiotics, Tetanus immunization, debridement, wound closure, and reporting if legally necessary [3,810]. Prophylactic antibiotics should be given based on the propensity for risk of the bite itself, the animal and its immunization status, and the time elapsed from injury to presentation. When choosing antibiotics, selection should be based on coverage for the aforementioned organisms and further guided by results from aerobic and anaerobic cultures. Medication with proper coverage includes oral amoxicillin and clavulanate, IV ampicillin-sulbactam, or doxycycline if allergic to penicillin $[3,8,10]$. An orangutan bite on the magnitude that our patient suffered was indeed high risk, and as such, $3000 \mathrm{mg}$ IV ampicillin-sulbactam was administered upon arrival to the emergency department.

The situation regarding zoo animal bites and getting immunizations or post-exposure prophylaxis is interesting. While they are exotic animals, primates in captivity undergo similar vaccination schedules as do humans. Orangutans share $97 \%$ of human DNA, so it's no surprise that they can also transmit and can become infected with similar respiratory and gastrointestinal diseases. In fact, the

Citation: Shaza Aouthmany MD, Noah Alcodray BA, Nasheed Fakhouri DO . Emergency at the Zoo: An Orangutan Bite Resulting in Thumb Amputation and Forearm Laceration $\quad$ Op Acc J Bio Sci \& Res 7(1)-2021. 
Orangutan Care Manual published by the Association of Zoos and Aquariums recommends following the American Academy of Pediatrics immunization schedule. In the case of an orangutan not being immunized early, the AZA strongly recommends all orangutans get yearly influenza vaccines, tetanus toxoid every 5-10 years, a one-time pneumococcus vaccine, and Haemophilus influenzae type b vaccine. Lastly, since rabies vaccines are not routine in humans, the decision to vaccinate an orangutan against rabies should be based on the exhibits exposure risk [11]. The CDC recommends a rabies preexposure vaccine in high risk groups such as veterinarians and animal handlers. Although this does not completely eliminate the need for therapy after rabies exposure, it eliminates the need for rabies immunoglobulin and reduces the number of vaccine doses [12]. It is reasonable to conclude that the decision to immunize an individual bitten by an orangutan should be based on a combination of vaccination history of the patient as well as the animal. In the emergency setting this information may not be immediately available and so it is prudent for the physician to act on their clinical acumen. In our patient's case, we chose only to administer the Tdap vaccine.

The patient experienced a tragic encounter while feeding an orangutan at a local zoo and suffered tremendous damage to her arm and thumb. Following her evaluation in the emergency department she was taken to the operating room where orthopedic surgeons extensively irrigated and debrided the wound. Surgeons then closed the forearm laceration and replanted the right thumb. Since 1990, there have been 16 primate escape or attacks at AZA accredited facilities resulting in human injury and zero reported cases of primate attacks resulting in death [13]. This indicates the safeguards currently in place are generally effective. It is difficult to ascertain what precautions should be instituted in the future to prevent such incidents from recurring but most emergency medicine departments are equipped to acutely treat them.

\section{References}

1. Cottier F, Tverberg V, Inall ME, Svendsen H, Nilsen F, et al. (2005) Water mass modification in an Arctic fjord through cross-shelf exchange: the seasonal hydrography hydrography of Kongsfjorden, Svalbard 102: 110.

2. Cottier FR, Nilsen F, Skogseth R, Tverberg V, Skarehamar J, et al. (2010) Arctic fjords: a review of the oceanographic environment and dominant physical processes Geol Soc London, Spec. Publ 344: 35-50.

3. Cottier FR, Nilsen F, Inall ME, Gerland S, Tverberg V, et al. (2007) Wintertime warming of an Arctic shelf in response to large-scale atmospheric circulation. Geophys Res Lett 34: L10607.

4. Muckenhuber S, Korosov AA, Sandven S (2016) Open-source featuretracking algorithm for sea ice drift retrieval from Sentinel-1 SAR imagery. The Cryosphere 10(2): 913-925.

5. Wiencke C, Hop H (2016) Ecosystem Kongsfjorden: new views after more than a decade of research. Polar Biology 39(10): 1679-1687.
6. Lalande C, Moriceau B, Leynaert A (2017) Spatial and temporal variability in export fluxes of biogenic matter in Kongsfjorden. Polar Biology 39(10): 1-14.

7. Bischof K, Convey P, Duarte P. Kongsfjorden as Harbinger of the Future Arctic: Knowns, Unknowns and Research Priorities, In H. Hop, C.

Wiencke (eds.), The Ecosystem of Kongsfjorden, Svalbard, Advances in Polar Ecology 2.

8. Hop H, Falk-Petersen S, Svendsen H (2006) Physical and biological characteristics of the pelagic system across Fram Strait to Kongsfjorden. Progress in Oceanography 71(2-4): 182-231.

9. Wang G, Guo C, Luo W, Cai M, He J (2009) The distribution of picoplankton and nanoplankton in Kongsfjorden, Svalbard during late summer 2006. Polar Biology 32: 1233-1238.

10. Falkowski PG, Barber RT, Smetacek V (1998) Biogeochemical controls and feedbacks on ocean primary production. Science 281: 200-206

11. Zhu ZY, Wu Y, Liu SM, Wenger F, Hu J, et al. (2016) Organic carbon flux and particulate organic matter composition in Arctic valley glaciers: examples from the Bayelva River and adjacent Kongsfjorden. Biogeosciences 13: 975-987.

12. Doney SC, Ruckelshaus M, Duffy JE, Barry JP, Chan F, et al. (2012) Climate change impacts on marine ecosystems. Annu Rev Mar Sci 4: 11-37.

13. Sunagawa S, Coelho LP, Chaffron S, Kultima JR, Labadie K, et al. (2015) Structure and function of the global ocean microbiome. Science 348 : 126-135.

14. Hegseth EN, Tverberg V (2013) Effect of Atlantic water inflow on timing of the phytoplankton spring bloom in a high Arctic fjord (Kongsfjorden, Svalbard). Journal of Marine Systems 113-114(1): 94-105.

15. Jain A, Krishnan KP (2017) Diferences in free-living and particleassociated bacterial communities and their spatial variation in Kongsforden, Arctic. J Basic Microb 57(10): 827-838.

16. Jain A, Krishnan KP, Singh A, Thomas FA, Begum N, et al. (2019) Biochemical composition of particles shape particle-attached bacterial community structure in a high Arctic ford. Ecol Indic 102: 581-592.

17. Shunan Cao, Fang Zhang, Jianfeng He, Zhongqiang Ji, Qiming Zhou (2020) Water masses infuence bacterioplankton community structure in summer Kongsforden. Extremophiles 24: 107-120.

18. Piquet AMT, Maat DS, Confurius-Guns V, Sintes E, Herndl GJ, et al. (2015) Springtime dynamics, productivity and activity of prokaryotes in two Arctic fords. Polar Biol 39: 1749-1763.

19. Zeng YX, Zhang F, He JF, Lee SH, Qiao ZY, et al. (2013) Bacterioplankton community structure in the Arctic waters as revealed by pyrosequencing of 16S rRNA genes. Anton Leeuw Int J G 103: 13091319.

20. Feng M, Zhang W, Xiao T (2014) Spatial and temporal distribution of tintinnid (Ciliophora: Tintinnida) communities in Kongsfjorden, Svalbard (Arctic), during summer. Polar Biology 37(2): 291-296.

21. Altshuler I, Hamel J, Turney S, Magnuson E, Lévesque R, et al. (2016) Variation of phytoplankton assemblages of Kongsfjorden in early autumn 2012: a microscopic and pigment ratio-based assessment. Environmental Monitoring \& Assessment 188(4): 1-13.

22. Damm E, Mackensen A, Budéus G, Faber E, Hanfland C. Pathways of methane in seawater: Plume spreading in an Arctic shelf environment (SW-Spitsbergen). Cont Shelf Res 25(12): 1453-1472.

23. Karl DM, Tilbrook BD (1994) Production and transport of methane in oceanic particulate organic matter. Nature 368(6473): 732-734.

24. Stawiarski B, Otto S, Thiel V, Gräwe U, Loick-Wilde N, et al. (2019) Controls on zooplankton methane production in the central Baltic Sea. Biogeosciences 16(1): 1-16.

25. Shakirov RB, Mau S, Mishukova GI, Obzhirov AI, Shakirova MV, et al. (2020) The features of methane fluxes in the western and eastern Artcic: A review. Part I. Geosystems of Transition Zones 4(1): 4-25.

26. Wāge J, Schmale O, Labrenz M (2020) Quantification of methanogenic Archaea within Baltic Sea copepod faecal pellets. Mar. Biol 167(10): 1-7.

27. Bižić M, Klintzsch T, Ionescu D, Hindiyeh MY, Günthel M, et al. (2020) Aquatic and terrestrial cyanobacteria produce methane. Science Advances 6(3): eaax5343.

Citation: Shaza Aouthmany MD, Noah Alcodray BA, Nasheed Fakhouri DO . Emergency at the Zoo: An Orangutan Bite Resulting in Thumb Amputation and Forearm Laceration Op Acc J Bio Sci \& Res 7(1)-2021. 
*Corresponding author: Shaza Aouthmany MD, Department of Emergency Medicine, University of Toledo College of Medicine and Life Sciences, Toledo, Email: shaza.aouthmany@utoledo.edu

Next Submission with BGSR follows:

- Rapid Peer Review

- Reprints for Original Copy

- $\quad$ E-Prints Availability

- Below URL for auxiliary Submission Link: https://biogenericpublishers.com/submit-manuscript/ 